Semina $\square \quad \mathrm{Nr} 14$

Scientiarum 2015

s. $140-145$

DOI: http://dx.doi.org/10.15633/ss. 1085

Piotr Urbańczyk

\title{
Copernicus Festival 2015: Geniusz
}

W dniach 18-23 maja 2015 roku w Krakowie odbyła się druga edycja poświęconego relacjom między nauką i kulturą Festiwalu Kopernika. Wydarzenie to zostało zorganizowane przez Centrum Kopernika Badań Interdyscyplinarnych oraz Fundację Tygodnika Powszechnego we współpracy z Muzeum Narodowym w Krakowie, Filharmonią im. Karola Szymanowskiego w Krakowie, Państwową Wyższą Szkołą Teatralną im. Ludwika Solskiego w Krakowie oraz Krakowskim Biurem Festiwalowym, a dofinansowane przez Gminę Miejską Kraków, Ministerstwo Kultury i Dziedzictwa Narodowego i Fundację Johna Templetona. W tym roku tematem przewodnim festiwalowych spotkań był fenomen geniuszu. Podczas sześciu dni uczestnicy i goście wykładów, debat, spotkań, koncertów, wystaw i projekcji filmów pytali, czym i kim jest geniusz, skąd wzięła się współczesna idea geniuszu, kto zasługuje na to miano i jakie są przejawy geniuszu w różnych aspektach rzeczywistości.

Festiwal został zainagurowany serią wydarzeń poświęconych postaci Józefa Hofmanna - polskiego pianisty i kompozytora obdarzonego również wybitnym talentem inżynierskim. W paśmie tym znalazł się wernisaż Ręka geniusza - Józef Hofmann, który odbył się w gmachu Galerii Krakowskiej. Następnie miejscem festiwalowych spotkań stała się Filharmonia Krakowska, gdzie o geniuszu Hofmanna debatowali Gregor Benko, Piotr Wierzbicki oraz Kinga Dębska. Odbył się tam także recital fortepianowy ukraińskiego pianisty Aleksandra Gawrylyuka - Whołdzie Józefowi Hofmanno- 
wi. W programie koncertu znalazły się utwory, które w interpretacji Hofmanna uchodziły za wyjątkowe.

Wydarzenia kolejnych dni festiwalu zostały uporządkowane w kilku pasmach. Każdy dzień zaczynał się Śniadaniem mistrzów. Były to spotkania z ważnymi polskimi naukowcami, które odbywały się w De Revolutionibus Books\&Cafe w mniej formalnej atmosferze niż ta, która $\mathrm{z}$ reguły towarzyszy wykładom akademickim czy dyskusjom panelowym. Pytania dotyczace osiagnięć, kariery zawodowej czy też relacji mistrz-uczeń można było zadać: Katarzynie Chałasińskiej-Macukow - profesor nauk fizycznych, rektor Uniwersytetu Warszawskiego w latach 2005-2012; Janowi Strelauowi - profesorowi psychologii znanemu z badań nad temperamentem, członkowi Polskiej Akademii Nauk, laureatowi Nagrody Fundacji na rzecz Nauki Polskiej; Janowi Woleńskiemu - filozofowi analitycznemu, logikowi i epistemologowi, profesorowi Uniwersytetu Jagiellońskiego uważanemu za kontynuatora myśli szkoły lwowsko-warszawskiej; Ryszardowi Nyczowi - polskiemu teoretykowi i historykowi literatury oraz Ryszardowi Tadeusiewiczowi - automatykowi i neurocybernetykowi, profesorowi nauk technicznych, trzykrotnemu rektorowi Akademii Górniczo-Hutniczej.

Program festiwalu zawierał także ofertę skierowaną do najmłodszych. Podczas Nauki czytania dzieci z krakowskich przedszkoli i uczniowie pierwszych klas szkół podstawowych rozmawiali o znanych bajkach, szukając w nich wątków naukowych. Z kolei Lekcje czytania skierowane były do licealistów. Podczas tych spotkań młodzież miała okazję porozmawiać o nauce z autorami i tłumaczami książek popularno-naukowych, m.in. Łukaszem Lamżą, Łukaszem Kurkiem i Mateuszem Hoholem.

Relacjom między nauką a duchowością poświęcone zostało pasmo nazwane Dwie księgi. Tytuł ten nawiązuje do powiedzenia pochodzącego od ojców Kościoła, a spopularyzowanego przez Galileusza, wedle którego zarówno badanie świata przyrody, jak i studiowanie pism objawionych sa dwiema komplementarnymi drogami prowadzacymi do odkrycia prawdy o Wszechświecie zaprojektowanym przez Stwórcę. Na spotkania w tej serii za- 
proszeni zostali autorzy krótkich rozpraw publikowanych przez Copernicus Center Press, a poświęconych nauce i wierze: Michał Heller, Andrzej Muszyński, Zbigniew Liana, Teresa Obolevitch i Wiktor Werner.

Spotkania z polskimi wynalazcami i projektantami niezwykłych rozwiązań technicznych odbywały się w cyklu zatytułowanym Inventio. Uczestnicy tych wydarzeń mieli okazje poznać założycieli studia developerskiego Incuvo - twórców aplikacji mobilnej Createrria oferujacej użytkownikom zabawę w tworzenie gier; Wiesława Bartkowskiego - projektanta tzw. interakcji ucieleśnionej, czyli rozwiązań technicznych w komunikacji człowiek-urządzenie projektowanych nie w tradycyjny sposób „na ekran”, ale tak, by lepiej odpowiadały one ludzkim umiejętnościom poznawczym i ruchowym, czy wreszcie zespół 3D FLY odpowiedzialny za polską technologię produkcji drukarek 3D.

Cztery festiwalowe wydarzenia odbywające się w popołudniowym paśmie zatytułowanym Perceptio nie stanowiły oferty powiązanej tematycznie. Wszystkie jednak miały na celu pokazanie zagadnienia genialności w różnorodnych aspektach. Pierwsze spotkanie z tego cyklu dotyczyło (jednocześnie) opery i prawa. $\mathrm{O}$ związkach między tymi dwiema dziedzinami ludzkiej działalności dyskutowali Ewa Łętowska i Krzysztof Pawłowski. Kolejne spotkanie w tym paśmie nazwane zostało Genius loci. Piotr Szarota, Adam Komorowski, Ewa Kuryluk i Andrzej Nowak próbowali na nim dociec, w jaki sposób narodził się geniusz Wiednia początku XX wieku. Cieszące się dużą popularnością spotkanie Messi kontra Ronaldo zgromadziło ekspertów piłkarskich: Rafała Ulatowskiego, Rafała Steca, Michała Okońskiego i Tomasza Pasiecznego, którzy prowadzili spór o geniusz obu tych piłkarzy. W ramach tego cyklu odbyła się także debata o geniuszu religijnym między Janem Kłoczowskim, Karolem Tarnowskim i Ludwikiem Wiśniewskim.

Niewątpliwie kulminacyjnym punktem każdego festiwalowego dnia był Wykład główny. Pierwszy z takich wykładów, zatytułowany Some Reflection on Nature of Genius, wygłosił fizyk i kosmolog z Uniwersytetu Kapsztadzkiego - George Ellis. Przedstawił w nim 
postaci 27 wybitnych uczonych zajmujacych się naukami matematycznymi, przyrodniczymi i technologia. Choć lista dobrana była w sposób nieco arbitralny, Ellis przy każdej z przedstawianych sylwetek wypunktował okoliczności, które sprawiły, że dana postać może zostać uznana za genialną. Wykład zakończył się dość ogólnikową puenta - geniusze, tak jak zwykli ludzie, widzą więcej, bo stoją na ramionach gigantów. Od zwykłych ludzi różnią się jednak tym, że wiedza, w którą stronę patrzeć.

Gościem tegorocznej edycji Festiwalu Kopernika była także Anna Wierzbicka - polska językoznawczyni z Australijskiego Uniwersytetu Narodowego w Canberrze. Jest ona autorka koncepcji semantycznego języka naturalnego, zgodnie z którą istnieją uniwersalne, wspólne wszystkim językom elementarne pojęcia. W wykładzie o tytule Wszechświat przemyśliwany na nowo, w osiemdziesięciu słowach prostych $i$ uniwersalnych próbowała ona podać przykład działania swojej teorii, tłumacząc na język uniwersalny fragmenty dzieł Kopernika i Keplera.

Które ze zdolności poznawczych są typowo ludzkie? Które dzielimy z innymi naczelnymi? Czy różnice między naszymi zdolnościami poznawczymi są jedynie ilościowe czy także jakościowe? Na takie pytania próbował odpowiedzieć Tetsuro Matsuzawa z Uniwersytetu w Kioto w wykładzie The Evolutionary Origins of $\mathrm{Hu}$ man Cognitive Development: Insights from Research on Chimpanzees. Porfesor Matsuzawa słynie z badań nad szympansami zarówno w warunkach laboratoryjnych, jak i środowisku naturalnym. Jego wykład był zobrazowany licznymi nagraniami zachowań małp. Niektóre z nich były bardzo zaskakujace - np. nagranie z badania, w którym szympans operuje liczbami porządkowymi lepiej niż człowiek i wydobywa je z pamięci pomimo beznadziejnie krótkiej prezentacji bodźca.

Ostatni z wykładów głównych o tytule Geniusze Wszechświata wygłosił Michał Heller - kosmolog i filozof, dyrektor programowy Festiwalu Kopernika. Przedstawił w nim uczonych, którzy najmocniej zapisali się $\mathrm{w}$ annałach historii kosmologii. Wśród nich znaleźli się Eratostenes z Cyreny, Kopernik, Einstein, Friedmann i Lemaître. Opowieść o każdej z tych postaci profesor Heller opa- 
trzył morałem - co czyniło danego człowieka geniuszem i w czym można go naśladować.

Po każdym z wykładów obywały się Debaty główne. O geniuszu władzy dyskutowali Andrzej Olechowski, Paweł Ścigaj oraz Aneta Czernatowicz-Kukuczka. O geniuszu zła wypowiadał się Marek Krajewski. O granicach języka debatowali Tetsuro Matsuzawa, Jolanta Antas i Mateusz Hohol. W końcu nad tym, czy w dzisiejszych czasach pojawienie się naukowego geniusza jest jeszcze możliwe, zastanawiali się Czesław Nosal, Michał Heller, Jerzy Stelmach oraz Bartosz Brożek.

Jeden z festiwalowych dni pozbawiony był wykładu o charakterze naukowym. Zamiast niego odbył się Wykład Lemowski. Do jego wygłoszenia zaproszony został pisarz science-fiction - Jacek Dukaj. Jego wypowiedź zatytułowana Banalność geniuszu dotyczyła pojęcia genialności. Przedstawił on, jak rozumie romantyczną i oświeceniową ideę geniuszu i która $\mathrm{z}$ nich - jego zdaniem - jest silniej obecna w dzisiejszych czasach. Następnie krakowski pisarz wzią udział w debacie poświęconej relacjom między nauką a science-fiction. Jego rozmówcą był filozof przyrody - Łukasz Lamża.

Oprócz wykładów, prezentacji i dyskusji Festiwal Kopernika oferował również spotkania o charakterze warsztatowym. Dotyczyły one m.in. twórczego pisania, enologii, obrazowania mózgu czy też psychologii poznawczej. Program festiwalu był bogaty także w wydarzenia o charakterze artystycznym. Oprócz wspomnianego już koncertu hofmannowskiego odbyły się dwa inne koncerty: Amadeus - przypowieść o Kainie i Ablu, podczas którego Capella Cracoviensis zagrała utwory Mozarta i Salieriego, a profesorowie Jerzy Vetulani i Dariusz Czaja opowiadali o różnicach między geniuszem a zwykłym człowiekiem, oraz Nowe neuronalne pętle - koncert Fisza, Emade i Wojciecha Bonowicza. Bardzo dużym sukcesem okazała się wystawa rzeźb podhalańskiego artysty - Stanisława Cukra, nazwana Bóg i forma, która odbyła się w Muzeum Sztuki i Techniki Japońskiej Manggha. Każdy dzień festiwalu kończył się natomiast projekcją filmu. Wśród prezentowanych w kinie Mikro produkcji znalazły się takie filmy, jak Amadeus (reż. Milos Forman), Kiet (reż. Giorgos Lanthimos), Ex Machina (reż. Alex Garland), Czy 
Noam Chomsky jest wysoki czy szczęśliwy? (reż. Michel Gondry) oraz The Visit (reż. Michael Madsen).

Tegoroczna edycja Festiwalu Kopernika cieszyła się ogromna popularnościa. W kilkudziesięciu wydarzeniach wzięło udział około siedem tysięcy osób. Szczegółowe sprawozdania z większości wydarzeń festiwalu odnaleźć można na stronach internetowych Tygodnika Powszechnego (www.tygodnikpowszechny.pl). Wiele spotkań zostało zarejestrowanych i będzie dostępne na kanale Centrum Kopernika Badań Interdyscyplinarnych w serwisie YouTube (www. youtube.com/CopernicusCenter). 